\title{
IDENTIFYING AS A LIBRARIAN: WHEN AND IF LIS GRADUATES IN NON-LIBRARY ROLES USE THE TITLE “LIBRARIAN” (Poster)
}

\author{
Abstract: \\ Résumé:
}

\section{Introduction}

The library and information science (LIS) profession is undergoing a time of transition. Positions for LIS graduates in "traditional" library-based settings are becoming increasingly rare (Demers et al. 2014; Clark 2013; Szkolar 2012; Fialkoff 2009; Stronski 2004). At the same time authors are highlighting the myriad opportunities available to LIS graduates in the information economy (Fagerheim 1999; Hovendick 2009). Given the changing nature of the work that is being performed by LIS graduates both inside and outside of libraries, the timing is appropriate to explore how practitioners choose to label themselves as professionals. LIS graduates working in non-library roles were selected as the target population of this study because their work provides them with multiple possibilities for self-labelling.

\section{Literature Review}

There are a number of definitions of professional identity available in the literature (see for example Billot 2010; Gibson, Dollarhide \& Moss 2010). Several key commonalities exist between many of the definitions. The first and most important is that professional identity is shared with a community. One's professional identity links one with a group of others who are working in similar environments or performing similar tasks and serves as a cohesive element that ties members of the practitioner community together. Professional identity is also viewed as highly fluid and changing over time based of personal experiences as well as external feedback.

Identity theories also argue that individuals possesses multiple identities and that social contexts will determine which identity or aspects or their identity is demonstrated (Smit, Fritz \& Mabalance 2010). An identity is more likely to influence a person's attitudes and behaviour if it has high salience (Burke Robertson 2011). Identity researchers have explored the question of which identities individuals will exhibit in response to various environmental or social cues (Dutton, Morgan Roberts \& Bednar 2010; Sacharin, Lee \& Gonzalez 2009; Chattopadhyay \&George 2001).

Bennett (2011) explored the idea that practitioners in the LIS field may juggle multiple professional identities, arguing that liaison librarians negotiate between "two significant professional identities: librarian and subject specialist" (p. 46). How LIS graduates in non-traditional roles manage multiple identities and whether there are 
overlapping identities for LIS graduates in different types of non-traditional roles has not been explored.

Librarian stereotypes may shed a light onto why, when, and where LIS practitioners choose to use the title or label of "Librarian". Stereotypes may have an impact on a group's status or ability to obtain rewards such as higher salaries or greater autonomy within a society. Many authors have written about negative stereotypes of librarianship and the impacts that these stereotypes may have on recruiting new entrants into the profession (Clemons 2011; Fallahay Loesch 2010; Potter 2009; Davis 2007; Peresie \& Alexander 2005; Isaacson 2000).

The nature of the librarianship and information science field(s) is another consideration in practitioner use of labels. The relationship between librarianship and information sciences has been explored by several researchers in the past. Marcia Bates in particular has explored both the range of roles available to LIS graduates and the nature of the LIS profession. In her 1999 article "The Invisible Substrate of Information Science", Bates explored both the "below-the-water-line" elements of the information science paradigm and the relationship between librarianship and information science. She identified factors that might attract researchers and practitioners to a field as including cognitive styles, research interests, and values (Bates 1999, 1043) and identified the following attributes of information scientists "wide subject interests, good skills with language, with getting the big picture about subject matter, rather than just working in the subject matter" (p. 1046). She described the shared information perspective of librarians and information scientists but differentiated them based on history and, in particular values perspectives, with information scientists tending to follow a "value neutral" approach while librarians follow a "service-oriented and empowerment-oriented" value system (Bates 1999, 1049).

\section{Methodology}

This poster presents data which were gathered in a grounded theory study concerning the professional identity experiences of library and information science (LIS) graduates in non-library roles. Grounded theory is an inductive research methodology that was designed to produce a new theory which is "grounded" in data (Glaser \& Strauss 1967; Glaser 1978; Glaser 1998). Key characteristics of a grounded theory study include theoretical sampling and constant comparison (Glaser 2001; Glaser 2009). The participants in this study were 20 professionals with Master's degrees in library and information science working outside of libraries. Their work included roles in information management, policy analysis, taxonomy and search tool development, library software development and sales, and independent consultants or information entrepreneurs.

The data collection technique employed in this project is semi-structured interviews. The semi-structured interviews included three sections. The first section of the interview asked participants to describe their career experiences from their decision to attend library school to the present. Participants were not interrupted during this narrative. The second section of the interview consisted follow-up questions in response to comments that participants made during the first section. The final section of the interview included questions developed in the interview guide to address topics such as educational experiences, communities, and how they identify or label themselves when communicating with others inside and outside of the profession. The results presented 
below provide details on the participants' responses to the question "Do you identify yourself as a librarian?"

\section{Results \& Discussion}

The question of how library and information science (LIS) graduates working outside of libraries identify themselves provided an interesting case through which to explore this question because these individuals may choose from multiple professional identities. Participants exhibited four response patterns when describing how they identified themselves to others in work and social situations: (1) always identifying as a librarian, (2) never identifying as a librarian, (3) sometimes identifying as a librarian, and (4) identifying as a "non-practicing" or "non-active" librarian.

The response patterns of those who always identified as a librarian, never identified as a librarian, and identified as a "non-practicing" or "non-active" librarian showed the sometimes competing influence of their emotional and intellectual attachment to librarianship (or information science) as well as their perceptions of group acceptance. Because of their work in non-library roles all of these individuals could be seen as potential outsiders to the library community. There was a perception among participants that librarianship is still largely seen as a profession which is practiced within the context of a library. For some, the dominant concern was avoiding conflict with library-based librarians, and these participants tended to use a non-librarian or modified librarian title. For others, a sense of affiliation with either librarianship or information science was the dominant motivating factor and they would either use the title of librarian or avoid the title of librarian in spite of challenges received from individuals both inside and outside of the LIS profession.

Those in the group who sometimes identified themselves as a librarian reflected a different primary motivation when self-categorizing. They decided on how to introduce themselves on a situation-by-situation basis based on their analysis of which title would provide the greatest benefit in their interactions with others. They were aware of both the positive and negative stereotypes of librarianship and their choices of self-labels reflected those stereotypes. When interacting with those who had a positive perception of librarians based on their service-orientation they used the librarian title, with one participant even describing this title as "an icebreaker" (Participant 005). When interacting with individuals who ascribed negative stereotypes of librarians they avoided this title.

\section{Conclusion}

The key contribution of this study is not in identifying how LIS professionals identify themselves but in exploring what motivated their use of various professional titles. This qualitative study sought to understand not just the variety of labels that could be used by LIS graduates in non-library roles but how these labels could be used to help express their professional identities and achieve their professional goals. This understanding contributes to the literature on professional identity and self-categorization that exists within the domains of social psychology and sociology, but it also has implications for the LIS profession.

Participants exhibited four response patterns when describing how they identified themselves to others in work and social situations: (1) always identifying as a librarian, (2) never identifying as a librarian, (3) sometimes identifying as a librarian, and (4) 
identifying as a "non-practicing" or "non-active" librarian. The three motivations observed in selecting a label were strength of affiliation with that label, perception of conflict with others inside or outside of the professional group caused by use of a given label, and the impact that the use of a label could have on the achievement of one's professional goals.

This study shows that LIS graduates who feel a strong affiliation with either the profession or librarianship or information science are willing to find ways to link various types of information work to the profession and may even act as powerful advocates for the profession. These data also show that LIS stereotypes are still impacting how professionals choose to introduce themselves. Encouraging LIS graduates in nontraditional roles to advocate for the LIS profession and LIS education may help to combat negative stereotypes. Finally, the study showed that LIS graduates in non-library roles do not feel fully accepted and integrated into the LIS profession and that there is still a strong link between librarianship and libraries-as-space. Further investigations of this topic may be conducted with larger samples or quantitative research methods to investigate correlations between professional labels and the motivations discussed here.

\section{Reference List:}

Bates, M. J. (1999). The invisible substrate of information science. Journal of the American Society for Information Science, 50(12), 1043-1050.

Bennett, M. H. (2011). The benefits of non-library professional organization membership for liaison librarians. The Journal of Academic Librarianship. 37(1), 46-53

Billot, J. (2010). The imagined and the real: identifying the tensions for academic identity. Higher Education Research \& Development, 29(6), 709-721. doi: 10.1080/07294360.2010.487201.

Bright, J. E.H., Earl, J. \& Adams, A. (1997). 'It's too short!': The impact on resume screening decisions of age, experience, format and content. Industrial and Organisational Psychology Conference Best Papers, 95-101. Retrieved from

http://www2.psy.unsw.edu.au/Users/JEarl/Web\%20papers/Bright,\%20Ear1\%20\&\%20Ad ams_best\%20paper\%201997.pdf

Burke Robertson, C. (2011). Organizational management of conflicting professional identities. Case Western Reserve Journal of International Law, 43(3), 603-623.

Chattopadhyay, P. \& George, E. (2001). Examining the effects of work externalisation through the lens of social identity theory. Journal of Applied Psychology, 86(4), 781-788.

Clark, J. C. (2013). What employers want: entry-level qualifications for music librarians. Notes, (March 2013), 472-493.

Clemons, J. (2011). Leading the way into the future of libraries. In Wallace, M. K.; Tolley-Stokes, R. \& Estep, E. S. The Generation X Librarian: Essays on Leadership, Technology, Pop Culture, Social Responsibility and Professional Identity. (91-98). Jefferson, North Carolina: McFarland \& Company. 
Davis, K. D. (2007). The academic librarian as instructor: A study of teacher anxiety. College \& Undergraduate Libraries. 14(2), 77-101.

Demers, P. (chair) et al. (2014). Expert Panel Report on The Future Now : Canada's Libraries, Archives, and Public Memory. Royal Society of Canada, Ottawa, ON.

Dutton, J. E.; Morgan Roberts, L.; \& Bednar, J. (2010). Pathways for positive identity construction at work: Four types of positive identity and the building of social resources. Academy of Management Review, 35(2), 265-293

Fagerheim, B. (1999). Moving outside the library: MLIS graduates in non-traditional careers. Alki, 15(1), 17.

Fallahay Loesch, M. (2010). Librarian as professor: A dynamic new role model. Education Libraries, 33(1), 31-37.

Fialkoff, F. (1976 reprinted 2009). Lousy job market, great career. Library Journal, 134(17), 8-8.

Gibson, D. M., Dollarhide, C. T., \& Moss, J. M. (2010). Professional identity development: A grounded theory of transformational tasks of new counselors. Counselor Education \& Supervision, 50(1), 21-38.

Glaser, B. G. (1978). Theoretical Sensitivity. Mill Valley, CA: Sociology Press.

Glaser, B. G. (1998). Doing Grounded Theory: Issues and Discussions. Mill Valley, Ca: Sociology Press.

Glaser, B. G. (2001). The Grounded Theory Perspective: Conceptualization Contrasted with Description. Mill Valley, CA: Sociology Press.

Glaser, B. G. (2009). Jargonizing Using the Grounded Theory Vocabulary. Mill Valley, CA: Sociology Press.

Glaser, B. G. \& Strauss, A. L. (1967). The discovery of grounded theory: strategies for qualitative research. New Brunswick, USA: Aldine Transaction

Hovendick, B. (2009). What I Learned About the Value of an MLIS Degree: An LIS Student's Perspective. Fast Facts - Recent Statistics from the Library Research Service. Colorado State Library. ED3/110.10/No. 271. Retrieved from http://www.lrs.org/documents/fastfacts/271_Student_Perspective.pdf

Isaacson, D. (2000). It isn't rocket science, it isn't even library science. American Libraries; 31(8), 48-48.

Leary, M. R. \& Price Tangney, J. (2003). The self as an organizing construct in the behavioral and social sciences, (pp. 3-14). In M. R. Leary \& J. Price Tangney (Eds) Handbook of Self and Identity. New York: The Guilford Press. 
Peresie, M. \& Alexander, L. B. (2005). Librarian stereotypes in young adult literature. Young Adult Library Services. 4(1), 24-31.

Potter, N. (2009). Why are we still defined by our building? Retrieved from http://www.cilip.org.uk/get-involved/special-interestgroups/diversity/Documents/NewProf_PotterBuilding_July09.pdf

Sacharin, V.; Lee, F. \& Gonzalez, R. (2009). Identities in harmony: Gender-work identity integration moderates frame switching in cognitive processing. Psychology of Women Quarterly. 33, 275-284.

Smit, B., Fritz, E. \& Mabalance, V. (2010). A conversation of teachers: In search of professional identity. The Australian Educational Researcher, 37(2), 93-106.

Stronski, L. M. (2004). Thinking Outside the Library: Employment Trends of Special Libraries Association Members. A Master's Paper for the M.S. in L.S. degree. Retrieved from https://ils.unc.edu/MSpapers/2968.pdf

Szkolar, D. (2012). Is a master's degree in library science a poor investment? A counter perspective to Forbes Magazine. Information Space. March 7, 2012.

White, H. S. (1986). The accredited MLS and the promised land. Library Journal, 111(8), 94-95. 